Jurnal Layanan Masyarakat (Journal of Public Service), vol 4 no 1 Tahun 2020, halaman 17-22

\title{
BIMBINGAN TEKNIS MANAJEMEN KEPALA SEKOLAH DAN PENGELOLAAN PEMBELAJARAN DI SMA RAPI MANADO
}

\section{(TECHNICAL GUIDELINES FOR SCHOOL HEAD MANAGEMENT AND LEARNING MANAGEMENT IN RAPI MANADO HIGH SCHOOL)}

\author{
Aswin Hermanus Mondolang \\ Jurusan Fisika, FMIPA Universitas Negeri Manado Sulawesi Utara \\ E-mail: aswinmondolang@yahoo.co.id
}

\begin{abstract}
A very urgent problem in Manado's RAPI High School is the management of school principals specifically covering: setting vision and mission, goals, work programs, and implementing school programs, carrying out supervision and monitoring, and evaluating work programs. The management of learning by teachers includes: the preparation of learning plans, the implementation and assessment of learning, and carrying out classroom action research. Through community service activities with the provision of technical management guidance to school principals and management of learning to teachers, it is expected to increase the ability of school principals and teachers. The Principal is able to compile the vision and mission of the school, compile or formulate school goals, compile school work programs and develop work programs for school principals. The teachers have also demonstrated the ability to carry out learning evaluations and are able to prepare CAR proposals. Through this activity it can be concluded that the activity participants can improve their management abilities, and the ability to manage learning in RAPI Manado High Schools.
\end{abstract}

Keywords: learning management, principal management, technical guidance

\section{abstrak}

permasalahan yang sangat urgen pada SMA Rapi Manado adalah manajemen kepala sekolah secara spesifik meliputi: penetapan visi dan misi, tujuan, program kerja, dan pelaksanaan program sekolah, melaksanakan supervisi dan monitoring, dan mengevaluasi program kerja. Pengelolaan pembelajaran oleh guru meliputi: penyusunan perencanaan pembelajaran, pelaksanaan dan penilaian pembelajaran, serta melaksanakan penelitian tindakan kelas. Melalui kegiatan pengabdian dengan metode pemberian bimbingan teknis manajemen kepada kepala sekolah maupun pengelolaan pembelajaran kepada para guru maka diharapkan peningkatan kemampuan Kepala Sekolah dan Guru. Kepala Sekolah mampu menyusun visi dan misi sekolah, menyusun /merumuskan tujuan sekolah, menyusun program kerja sekolah dan menyusun program kerja kepala sekolah. Para guru juga telah memperlihatkan kemampuan dalam melaksanakan evaluasi pembelajaran serta mampu menyusun proposal PTK. Melalui Kegiatan ini dapat disimpulkan bahwa para peserta kegiatan (Kepala Sekolah dan guru-guru SMA Rapi Manado) dapat meningkatkan kemampuan manajemennya, dan kemampuan mengelola pembelajaran di SMA Rapi Manado.

Kata Kunci: Bimbingan teknis, manajemen kepala sekolah, pengelolaan pembelajaran. 


\section{PENDAHULUAN}

Sekolah Menengah Atas (SMA) Rapi Manado adalah salah satu unit sekolah yang dikelola oleh Yayasan Rapi Manado. Sekolah ini sejak berdirinya telah mengalami berbagai permasalahan, mulai dari krisis manajemen pihak Yayasan yang sudah dua kali mengalami perubahan manajerial, juga mengalami persoalan lokasi/tempat melaksanakan kegiatan belajar mengajar. Sejak berdirinya SMA Rapi berlokasi di Jln. Martadinata Paal dua Kota Manado sampai tahun 1992. Tetapi karena persoalan manajemen Yayasan maka sejak tahun 199 SMA Rapi Manado berpindah ke lokasi yang baru yaitu di Jln. Loreng No. 123 Kelurahan Bailang Kecamatan Bunaken Kota Manado Provinsi Sulawesi Utara.

Sejak SMA RAPI melaksanakan kegiatan belajar-mengajar di lokasi yang baru di (Jln. Loreng No. 123 Kelurahan Bailang Kecamatan Bunaken) terjadi berbagai permasalahan yang baru seperti: lokasi yang masih sulit dijangkau oleh para guru dan siswa karena akses jalan yang belum memadai, jumlah rumah penduduk yang masih kurang, lingkungan sekolah yang masyarakatnya masih tergolong pada taraf hidup yang di bawah rata-rata, juga krisis manajemen kepala sekolah akibat sering bergantinya personal Kepala Sekolah, dan tenaga Guru yang direkrut oleh Yayasan yang belum berkualifikasi yang memadai.

Data siswa dan tanaga guru dari SMARapi saat ini sebagai berikut: Jumlah Siswa Kelas 10: 19 Siswa, Kelas 11: 26 Siswa, Kelas 12: 56 Siswa; Jumlah Guru Yayasan: 9 orang (termasuk kepala sekolah), Guru PNS: 7 orang. Jarak sekolah ini dengan kampus Unima $\pm 56 \mathrm{~km}$.

Namun seiring dengan perkembangan/kemajuan kota Manado, Sekolah ini terus membenahi diri tetapi tentunya belum cukup memuaskan sebagai sebuah lembaga Sekolah yang mampu bersaing dengan sekolah-sekolah lainnya sehingga sangat mempengaruhi kualitas sekolah.

Jika diamati dari segi potensi yang dimiliki olah sekolah ini, dapat diungkapkan sebagai berikut: sekolah ini berada di atas lokasi tanah seluas $\pm 1 \mathrm{Ha}$, memiliki 6 ruang kelas, memiliki 1 ruang kantor, dan memiliki halaman sekolah yang masih luas seperti yang dapat dilihat dari beberapa foto berikut:
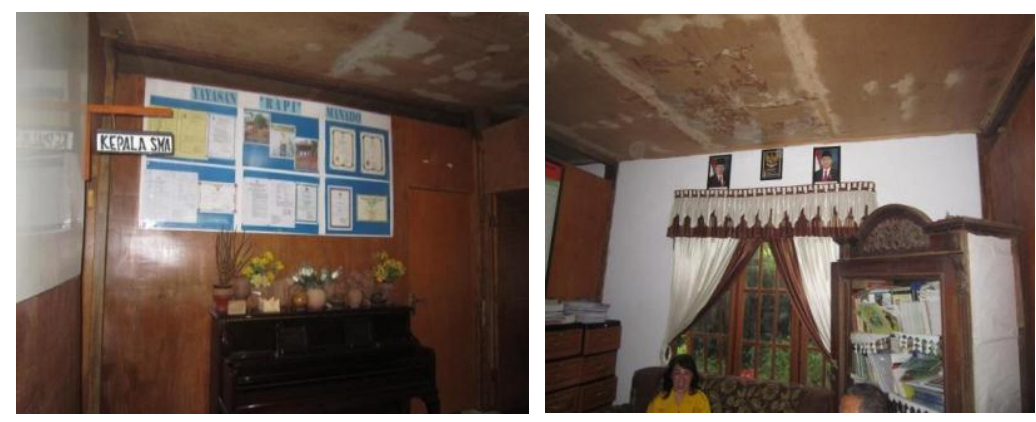

Gambar. 1 Ruang Kepala Sekolah 


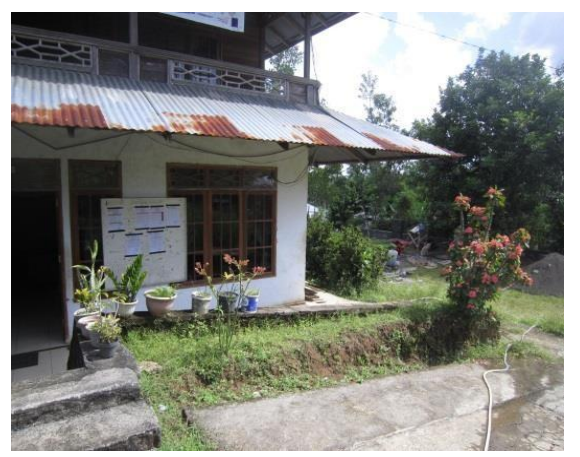

Gambar 2. Bangunan Kantor Sekolah

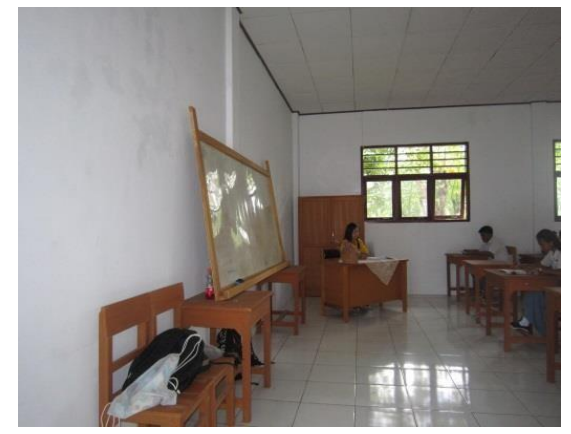

Gambar 3. Kegiatan Belajar-Mengajar

Dari gambar-gambar di atas sangat jelas menunjukkan bahwa salah satu indikator dari sistem manajemen yang belum baik adalah masih terpampangnya gambar Presiden dan Wakil Presiden yang belum diganti (gbr. 1), papan data guru yang tidak sesuai dengan fakta sebenarnya, bangunan yang dijadikan kantor sekolah yang tidak menggambarkan kantor yang baik (Gbr. 2), lingkunga ruang- ruang kelas yang tidak terawat, kegiatan belajar-mengajar yang kurang kondusif (Gbr. 3). Di samping hal-hal tersebut, sekolah ini juga walaupun memiliki luas halaman yang cukup luas tapi tidak dimanfaatkan secara maksimal oleh pihak sekolah (Gbr. 4) sebagaimana yang tergambarkan di bawah ini:


Gambar 4. Halaman Sekolah

Selain hal-hal sebagaimana diutarakan di atas, dari pengamatan dan hasil wawancara dengan Kepala Sekolah SMA Rapi juga diketahui bahwa pengelolaan pembelajaran yang dilakukan oleh para guru masih sangat jauh dari yang diharapkan, seperti: para guru sangat terbatas kemampuannya dalam mempersiapkan RPP (Rencana pelaksanaan Pembelajaran) yang merupakan salah satu faktor yang menentukan kualitas pembelajaran, juga para guru dalam melaksanakan pembelajaran masih tergolong konvensional dan tidak menunjukkan kualitas guru yang baik (ditunjukkan oleh gbr. 5 di atas). Data yang ada di kantor sekolah tidak ditemukan perangkat pembelajaran yang teradministrasi dengan baik.

Berdasarkan Analisis Situasi di atas, maka permasalahan yang sangat urgen pada SMA Rapi Manado adalah berkaitan dengan manajemen dari kepala sekolah dan pengelolaan 
pembelajaran oleh para guru. Permasalahan manajemen kepala sekolah secara spesifik meliputi: penetapan visi dan misi sekolah, penetapan tujuan sekolah, penyusunan program kerja sekolah, dan melaksanakan program sekolah, melaksanakan supervisi dan monitoring, dan mengevaluasi program kerja. Untuk pengelolaan pembelajaran oleh para guru secara spesifik meliputi: penyusunan perencanaan pembelajaran, pelaksanaan dan penilaian pembelajaran, serta melaksanakan penelitian tindakan kelas. Hal-hal tersebut merupakan pernasalahan yang sangat urgen yang perlu dibenahi dan ditingkat mutu layanannya.

\section{METODE PENGABDIAN MASYARAKAT}

Metode kegiatan yang akan dilakukan adalah sebagai berikut: Melaksanakan bimbingan teknis penyusunan visi dan misi sekolah, Melaksanakan bimbingan teknis penyusunan/perumusan tujuan sekolah, Melaksanakan bimbingan teknis penyusunan program kerja kepala sekolah, Melaksanakan bimbingan teknis pelaksanaan program kerja sekolah, Melaksanakan bimbingan teknis supervisi, monitoring dan evaluasi dan rekomendasi, Bersama kepala sekolah, melaksanakan bimbingan teknis dan workshop tentang penyusunan program pembelajaran, Bersama kepala sekolah, melaksanakan bimbingan teknis dan workshop tentang pelaksanaan program pembelajaran, Bersama kepala sekolah, melaksanakan bimbingan teknis dan workshop tentang melaksanakan evaluasi pembelajaran, Bersama kepala sekolah, melaksanakan bimbingan teknis dan workshop tentang penyusunan proposal PTK.

\section{HASIL DAN PEMBAHASAN}

Hasil dan luaran yang dicapai dalam kegiatan ini sebagai berikut:

Kepala Sekolah mampu menyusun visi dan misi sekolah, menyusun /merumuskan tujuan sekolah, menyusun program kerja sekolah dan menyusun program kerja kepala sekolah. Kepala Sekolah memahami teknis supervisi, monitoring danevaluasi dan rekomendasi. Kemampuan-kemampuan tersebut nampak secara jelas melalui poster yang dipampang di ruang kepala sekolah seperti yang terlihat pada gambar 5.



Gambar 5. Ruang Kerja Kepala 
Para guru mampu menyusun program pembelajaran dan melaksanakan program pembelajaran seperti pada gambar 6 berikut:
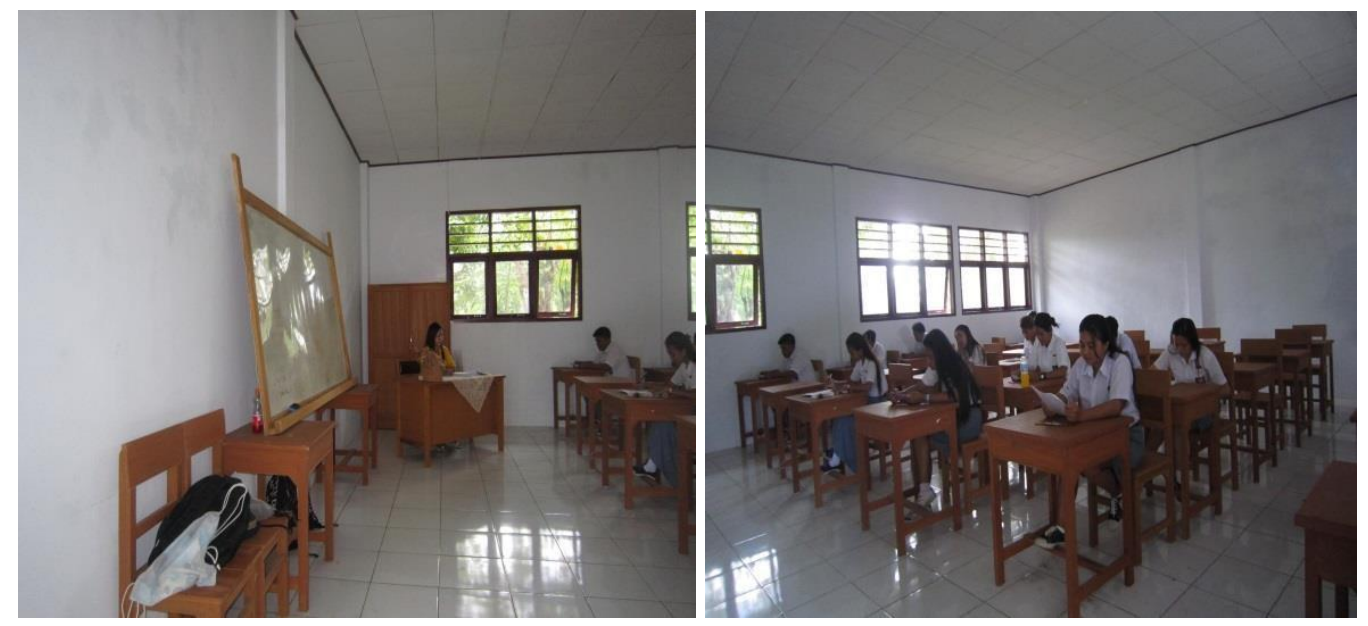

Gambar 6. Kegiatan pembelajaran di salah satu ruang kelas

Selain kegiatan-kegiatan tersebut di atas sebagai wujud nyata hasil kegiatan pengabdian, Para guru juga telah memperlihatkan kemampuan dalam melaksanakan evaluasi pembelajaran serta mampu menyusun proposal PTK.

Hasil yang juga sangat menunjukkan perubahan pada kondisi sekolah adalah perubahan lingkungan sekolah yang sangat signifikan sebagai akibat dari meningkatnya kemampuan manejemen kepala sekolah yang dapat dilihat pada gambar berikut:

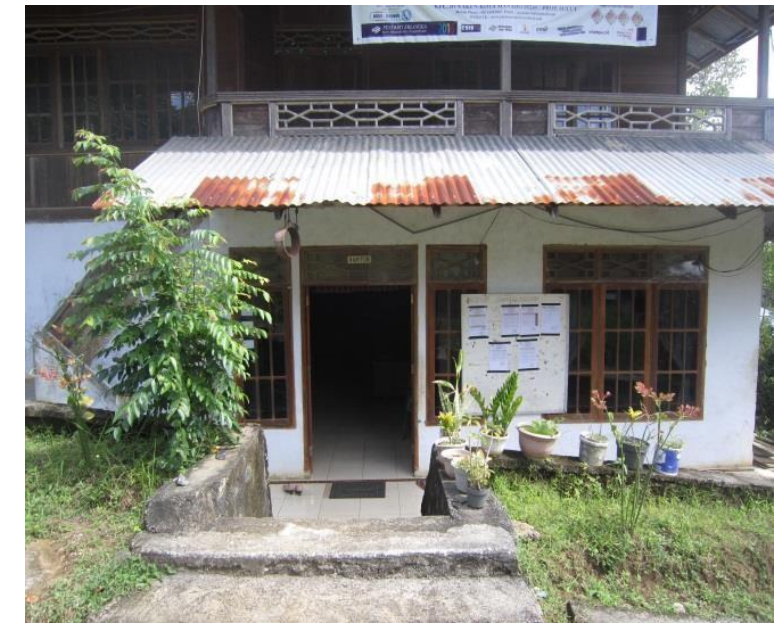

Gambar 7. Sebelum kegiatan



Gambar 8. Sesudah kegiatan 


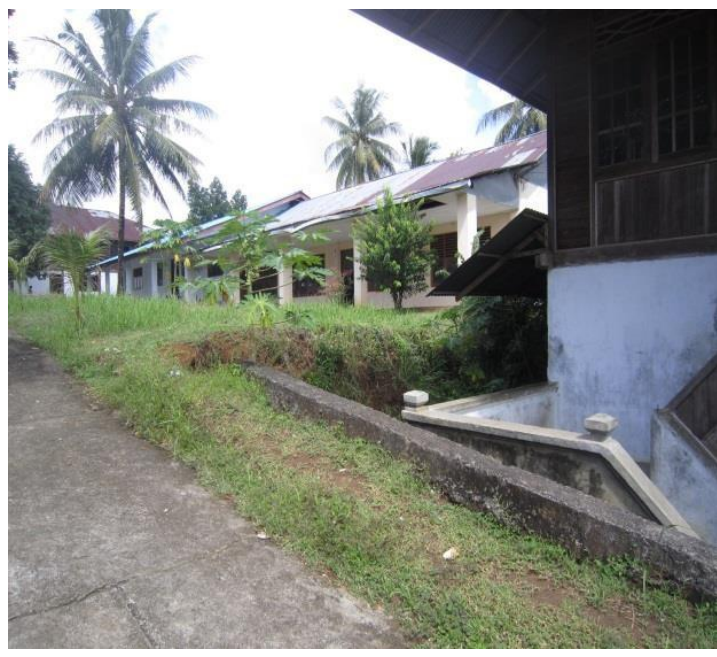

Gambar 9. Sebelum kegiatan

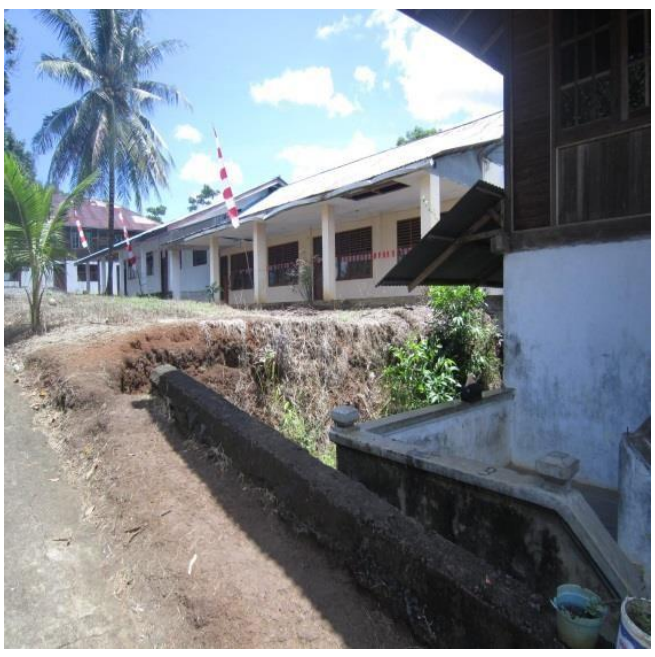

Gambar 10. Sesudah kegiatan

\section{PENUTUP}

\section{Simpulan dan Saran}

Melalui Kegiatan ini dapat disimpulkan bahwa para peserta kegiatan (Kepala Sekolah dan guru-guru Yayasan Rapi di Kota Manado) dapat meningkatkan kemampuan manajemen Kepala Sekolah, dan kemampuan mengelola pembelajaran di SMA Rapi Manado. Kehadiran Perguruan tinggi di tengah masyarakat (khususnya di lembaga pendidikan Sekolah) dalam memberikan pemahaman serta ketrampilan perlu terus ditingkatkan dan diperluas kepada Kepala Sekolah dan para guru di sekolah-sekolah lainnya.

\section{DAFTAR PUSTAKA}

Badan Standar Nasional Pendidikan. 2006. Rancangan Pembelajaran. Jakarta: Badan Standar Nasional Pendidikan.

Departemen Pendidikan Nasional. 2004. Manajemen Sekolah .Jakarta: Badan Penelitian dan Pengembangan Pusat Kurikulum.

Djemari Mardapi. 2008. Teknik Penyusunan Instrumen Tes dan NonTes. Jakarta: Mitra Cendikia.

Hayat, Bahrul. 2008. Prinsip-prinsip dan Strategi Penilaian di Kelas. Jakarta: Pusat Penilaian Pendidikan, Badan Penelitian dan Pengembangan, Departemen Pendidikan Nasional.

Seifert, Kelvin, 2012. Pedoman Pembelajaran \& Instruktur Pendidikan. Jogjakarta: IRCisoD.

Uno, Hamzah B. 2012. Perencanaan Pembelajaran. Jakarta: Bumi Aksara. 